\title{
Vulvar Cancer pT3 TNM Finding v8
}

National Cancer Institute

\section{Source}

National Cancer Institute. Vulvar CancerpT3 TNM Finding v8. NCI Thesaurus. Code C139605.

Vulvar cancer with tumor of any size with extension to any of the following:

upper/proximal two-thirds of the urethra, upper/proximal two-thirds of the vagina, bladder mucosa, or rectal mucosa; or fixed to pelvic bone. (from AJCC 8th Ed.) 